\title{
Factors Limiting the Usage of ICT in the Delivery of Management Services in Public Secondary Schools in Siaya County
}

\author{
MS. Oluoch Dornela Akomo \\ Nyabeda Secondary School, Box 56 - 40628. Mutumbu \\ Dornelaoluoch@yahoo.com. \\ Dr. Jack Odongo Ajowi* \\ Jaramogi Oginga Odinga University of Science and Technology, Box 210 - 40601. Bondo \\ jackajowi@yahoo.com \\ Prof. Joseph Bosire DVC (Academics) \\ Jaramogi Oginga Odinga University of Science and Technology, Box 210 - 40601. Bondo \\ jbosire@jooust.ac.ke
}

Doi:10.5901/mjss.2015.v6n2p554

\begin{abstract}
This study was set to determine the effect of integrating ICT use in the delivery of services in public secondary schools in Siaya County, Kenya. Although many secondary schools introduced computers in great numbers starting early 1990s, there are limited information on their use to facilitate delivery of services in school administration and management. The extent to which ICT is being used in school management in secondary schools, the types of administrative uses of ICT by school managers and challenges affecting the integration of ICT in the management systems in secondary schools needed to be adequately addressed. The purpose of this study was therefore to determine the effect of integrating ICT in the delivery of services in public secondary schools in Siaya County. The study objectives were to determine the areas in which ICT is being used in the delivery of management services in public secondary schools in Siaya County and to recommend strategies of enhancing ICT in the delivery of services in public secondary schools in Siaya County. The theoretical framework that guided the study was Social Transformation Theory in Education and Visscher (1992) conceptual model of school information system, which were used to show the relationship between variables. The research design that was used is descriptive survey. The study population consisted of 167 Principals, 167 Secretaries, 167 Deputies, 167 Bursars/Accounts' clerks and 334 Heads of Departments. Purposive sampling technique was used to identify 48 schools that had incorporated ICT in their management system in secondary schools. Saturated sampling technique was used to select 48 principals. Purposive sampling technique was used to select one head of department in charge of examinations and one in charge of boarding in each sampled schools, giving a total of 96 heads of departments, 48 Deputy Principals, 48 Secretaries and 48 Bursars/ Accounts' clerk. Questionnaires was administered to the H.O.Ds, Deputy Principals and Bursars/Accounts' clerks to gather data on the level of ICT incorporation in management in secondary schools. Interviews with school principals and Secretaries captured data on their role in provision of ICT equipment for school management systems and the challenges they face in ICT use in school administration system. To ensure validity and reliability of the research instruments, experts from the School of Education, Jaramogi Oginga Odinga University of Science and Technology scrutinized the research instruments. A pilot study of 5 schools was equally conducted in the schools not sampled for the study.
\end{abstract}

Definition of Keywords: Information and Communication Technology (ICT), Educational Management Practices, Effect and Integration.

\section{Introduction}

The use of Information and Communication Technology (ICT) in schools has become widespread in many countries throughout the world. The extent to which it has been incorporated into the school systems vary widely from simply as a tool to help produce documents to one that is fully integrated into the whole school management practices Osodo (2010). Education institutions in Kenya in the $21^{\text {st }}$ century, just as in other parts of the world, are increasingly becoming complex multidimensional organizations requiring tremendous input in terms of human, financial and physical resources. Such school working environments are bound to overwhelm the abilities of today's' teacher and administrator if they are not 
aided in the performance of their school administrative duties. Therefore, these developments demand that educational institutions modernize their tools of conducting business to enhance the effectiveness of management and leadership.

According to Ray and Davis (1991), the potential of information communication and technology (ICT) to enhance human capabilities and revolutionize management of organizations was first realized in other sectors of human society, mostly in the business world and the military, other than in education. The importance of ICT contribution is also widely recognized both in the workplace and at home. These examples are just a few pointers which show that ICT is becoming a vital enabling tool that can no longer be ignored in the management of schools.

A study carried out in The United States as revealed by Bird (1984) indicate that USA was the pioneer in this field, developing the first business applications for applications such as finance and payroll back in the 1960s. Many other countries needed 15-20 more years to reach the same level of school administrative computing. Some countries, especially developing countries, still await the entrance to the initiation stage due to a lack of capable professionals, technical infrastructure and finance. Countries that were active in this area included Hong Kong, The United Kingdom, New Castle and Netherlands. All these countries had their first school administration computer applications by the end of the 1970s. it is interesting to note that even though a number of developed countries had initiated school information system, integrating it into school administrative system came with challenges such as lack of technology applications, computer infrastructure and clear education management information policy system. These and many other challenges call for more research in this area to ascertain the level of education management information system inception in secondary schools.

A study carried out by Visscher (1999) found that school information systems are not only designed for assisting school managers, but are also used by clerical staff in registering, processing and out putting students, finance, personnel and other data for day to day routine work. The research further showed that school information systems are mainly used for clerical work, with managers so far failing to receive much benefit from these systems. School information systems may include student monitoring system for evaluating long term student progress. Student progress data can be entered into these computer-assisted systems which thereafter produce student progress reports that can be used at both teacher and management level. The external school systems designed for feeding back school performance data (indicating schools performance data compared with that of other schools) can also be factored in. Integration of such systems into school management is still weak at present but will grow in importance for school management with a move towards performance related pay, observes Visscher (2001), It is therefore important that the present study should provide ways in which ICT use can be promoted in school management.

According to the Ministry of Education (2008) on the Final Report on the Kenya Education Management Capacity Assessment (KEMACA), many processes in the school sector seem to take too long. The time required for staffing approvals and movements, timetabling, student financial records, admission and student examination records is always cited as taking too long. The government strategy for the development of Education management information system is to develop an electronic-based infrastructure at all levels, to support processing, use, sharing and dissemination of available data and information. This has not been adequately realized at secondary school level to any meaningful degree (MOE, 2008).

In Kenya, MOEST (2005) observes that ICT integration in school management practices involve information system based on one or more computers, consisting of a data bank and one or more computer applications which altogether enable the computer-supported storage, manipulation, retrieval and distribution of data to support school management. This implies that specific nature of a particular school information system is dependent on the number and character of computer applications (e.g. student administration, personnel management student timetabling are all included in the school information system. In other cases, computer technology also provides policy-making information to school organizational staff that supports them in their strategic management activities. The activities of teachers and clerical employees in schools result in a data bank filled with hopefully, up to date data on the school organization and its environment. This data bank enables the production of valuable managerial information like trends, patterns, forecast, retention rate, dropout rate and graduation rates of students.

Kavagi (2001) noted that from the early 1990s, increasing numbers of secondary schools in Kenya acquired computers for use in the institutions. The initiative was partly due to pressure from government and NGOs. Despite the central role occupied by administration in the schools, for a long time there has been little emphasis on the implementation of computer technology in management in the Kenyan Schools. However since the turn of this century, the Kenyan Government has been working towards the realization of transforming all educational institutions in the country to be ICT compliant as attested by the interest shown on ICT in a number of government policy documents (Republic of Kenya, 2005). It was therefore important to carry a study on how secondary schools have incorporated ICT in school management. 
Just like in other counties in Kenya, (KEMACA 2008) found out that ICT use in delivery of services in secondary schools in Siaya County still face a major challenge. According to the study which was a project of the Ministry of Education, Education Management Information System in schools was seen to play critical role in the provision of timely, reliable and accurate data and information for use at all levels of the education system. However, the findings indicated that secondary schools experience difficulty in maintaining proper records that could form the primary data for effective EMIS at the school level.

ICT integration in school management is becoming increasingly used in schools, with the intention of enhancing effectiveness and efficiency in the delivery of services. However, many processes in the school programs still seem to take long. There are delays in school time-tabling, processing of student financial and examination records, mishandling of files that contain MOE data forms, TSC data forms, staff return files and financial return files that often get lost during the handing over-taking over by the school principals. Even though the government of Kenya, working very closely with Kenya's private sector, Kenya Ministry of Education Science and Technology (MOEST), and Computer for Schools Kenya (CPSK) has assisted schools to integrate ICT in their management system, the effect of this initiative on the delivery of services has not been ascertained. Therefore the focus of this study was to determine the effect of ICT in the delivery of services in public secondary schools in Siaya County in Kenya. The purpose of this study was set to determine the effect of integrating ICT on the delivery of services in public secondary schools in Siaya County, Kenya. Specifically the study was guided by the following objectives: To determine the areas in which ICT is used in the delivery of management services in public secondary schools. And to recommend strategies of enhancing ICT in the delivery of management services in public secondary schools.

\section{Research Methodology}

\subsection{Research Design}

This study adopted the descriptive survey. According to Mugenda and Mugenda (2003), a descriptive survey involved asking a large group of respondents' questions about particular issues or phenomenon. Descriptive survey was adopted in this study for various reasons. It allowed the researcher to adopt a holistic approach in the study sampled schools. Secondly, it was easy to use research tools like questionnaires and interview schedules.

The study was carried out in Siaya County of Kenya. Due to factors such as expense, accessibility and proximity of the county to the researcher, Siaya County was considered appropriate for the research. Siaya County borders Busia County to the North, Kakamega County to the North East, Vihiga County to the East, Kisumu to the South East, with Lake Victoria to the South and West. It has an area of 2,530.5 square $\mathrm{km}$. Poverty level index is $57.9 \%$ (Rural) and $37.9 \%$ (Urban) (Siaya District Development Plan, 2002). Resources available are agricultural land, fisheries, indigenous forests, rivers, and timber. The main economic activities are subsistence farming, livestock keeping, fishing, rice farming and small scale trading. Other economic activities in the County include wage employment, rural self-employment, and urban self-employment. The County has six Districts namely Gem, Ugenya, Bondo, Siaya, Ugunja, and Rarieda and a total of 167 registered public secondary schools: 16 provincial boys' secondary schools, 20 provincial girls' secondary schools, 130 mixed public secondary schools, and two national schools (Siaya District Strategic Plan 2005-2010). Siaya County was chosen because of its accessibility and proximity to the researcher. More importantly, according to Siaya County Education Report (2011), the County's inception of ICT in secondary schools is relatively low. The study population consisted of 167 Principals, 167 Deputies, 334 Heads of Departments in the examination and boarding section, 167 Secretaries and 167 Bursars/ Accounts' clerks. According to Siaya County Education Report (2011), the estimated registered secondary schools comprise 16 provincial boys' secondary schools, 20 girls' schools, 130 mixed public secondary schools and two national schools.

Purposive sampling technique was used in selecting schools that have incorporated ICT in the delivery of their management systems. Purposive sampling technique was appropriate because according to Kombo and Tromp (2006), it selects participants based on a particular purpose of the study. In this case, it selected participants that had the required information: only those that had incepted ICT in the delivery of management services in secondary schools in Siaya County were used for the study. Saturated sampling technique was used in selecting one principal and one deputy from each sampled school, giving a total of 43 principals and 43 deputies respectively, after 5 principals (10\%) and 5 deputies (10\%) will have been involved in pilot study. Saturated sampling technique was convenient because the elements under study are few. A purposive sampling technique was used in selecting one secretary, one Bursar/Accounts' clerk and one Head of Department in the Examinations and one in Boarding Department in each sampled school, giving a total of 43 Secretaries, 43 Bursars/Accounts' clerks, 86 H.O.Ds respectively after which $10(10 \%)$ were involved in pilot study. The 
departments were purposively selected since they document a lot of information regarding other departmental documents and student management records. Data was collected through the use of questionnaires, interview schedules, and observation schedule.To ensure the validity of the research instruments, at least two members at the School of Education at Jaramogi Oginga Odinga University of Science and Technology who are experts in this area of study scrutinized the research instruments. According to Mugenda and Mugenda (2003), validity is the degree to which results obtained from the analysis of the data actually represent the phenomenon under study. If such a data is a true reflection of the variables, then the inferences based on such data will be accurate and meaningful. Therefore, the suggestions of the experts were used in revising the instruments before preparing the final copy.

Reliability refers to the quality of a measured procedure that provides repeatability and accuracy of the research instruments (Gall and Borg, 2006). Therefore, before the instruments are used to collect the data for the study, a pilot study was conducted in three schools that were selected for main the study: one in mixed school, girls boarding secondary school and the other in boys' secondary school. This ensured that the study got the intended information from the questionnaires. The pilot study also helped to identify the problems the respondents would encounter while filling the forms. According to Gall and Borg (2006), a pilot study also provides data for making estimates of time and the cost for completing various phases of the research. Pilot study was thus useful in establishing extraneous factors that might have affected the research results.

Permission to carry out the research was sought from the Ministry of Education Science and Technology through the School of Graduate Studies of Jaramogi Ogimga Odinga University of Science and Technology, and the County Director of Education, Siaya. Letters notifying various institutions of the intended study were collected by the researcher two weeks before the start of the study. Each of the sampled schools was visited twice or more. The first visit was for introduction, familiarization, and distribution of questionnaires. The second visit was for the interview and collection of questionnaire. The in-depth interviews were conducted with the Principals through discussions in a semi-formal environment. This approach was preferred by researchers because it gave the participants a free atmosphere thereby encouraging openness (Kombo, \& Tromp, 2006).

Data collected from questionnaires and interviews were processed and analyzed in line with the research objectives. Information on areas in which ICT was being used in the delivery of management services were analyzed descriptively through percentages, tabulation, mean and frequencies. Information on the effect of integrating ICT in the delivery of management services in secondary schools were analyzed descriptively though tabulations, frequencies, and percentages. This was done using the H.O.Ds Questionnaire, document analysis and through interview schedules. Tables and descriptions were categorized depending on the categories of respondents. Information on the availability of computers, computing materials and existing government and school ICT management policies were analyzed through document analysis from various schools and government documents. This was done by drawing tables and listing available documents. They were interpreted as per the research objectives. Documents from various Heads of Departments were also be analyzed through tabulations, frequencies, range and mean. Analysis of data seeking opinions about factors limiting the use of ICT in the delivery of management services in secondary schools were analyzed through tabulations, percentages and frequencies. Qualitative data from interview schedules from the principals were transcribed, and written in verbatim according to various themes, categories and sub categories as they emerged during the study (Mugenda and Mugenda, 2003). Information on strategies of enhancing ICT in the delivery of services in secondary schools were equally analyzed descriptively.

\section{Results and Discussion}

\subsection{Factors Limiting the Usage of ICT in the Delivery of Management Services in Public Secondary Schools.}

The research question responded to was; what are the factors limiting the use of ICT in the delivery of services in public secondary schools in Siaya County? 
Table 4.9. Showing Factors Limiting the Usage of ICT as reported by principals $(n=43)$, deputy principals $(n=43)$, Heads of Departments $(n=86)$, Secretaries $(n=43)$, Bursars/Clerks $(n=43)$.

\begin{tabular}{lccccc}
\hline Factors Limiting the Usage of ICT & $\begin{array}{c}\mathbf{P} \\
\mathbf{f} \%\end{array}$ & $\begin{array}{c}\text { DP } \\
\mathbf{f} \%\end{array}$ & $\begin{array}{c}\text { HOD } \\
\mathbf{f} \%\end{array}$ & $\begin{array}{c}\text { SEC } \\
\mathbf{f} \%\end{array}$ & $\begin{array}{c}\text { BU/CLK } \\
\mathbf{f} \%\end{array}$ \\
\hline Inadequate ICT in the departments & & & & & \\
Few members of staff are skilled in ICT usage & 43100 & 43100 & 86100 & 43100 & 43100 \\
Financial inadequacy for purchasing ICT equipments & 43100 & 43100 & 86100 & 43100 & 43100 \\
Virus infection on the data stored in ICT equipments & 43100 & 43100 & 86100 & 43100 & 43100 \\
Negative attitude of the staff on ICT usage in schools & 3786 & 3683 & 8498 & 3888 & 3581 \\
Fear of access of confidential data stored in ICT. & 3581 & 3070 & 7587 & 3684 & 3274 \\
Personalization of the school computers by the school administration & 3070 & 2865 & 6778 & 3172 & 2660 \\
Lack of electricity in schools & 2865 & 2558 & 5665 & 2865 & 2456 \\
The high cost of maintaining the ICT equipments & 2047 & 2353 & 5058 & 2558 & 2047 \\
\hline
\end{tabular}

KEY: HT= Head Teachers, HoDs =Heads of Departments.

Table 4.9 reveals that there were several factors that were limiting the usage of ICT in secondary schools. The study indicated that the major factors were; inadequate ICT facilities in the department, few members of staff had skills in the usage ICT equipments, and inadequate finance. Other factors such as virus infection on the stored data, negative attitude of the staff on the usage of ICT in management and fear of access of confidential data stored on ICT equipments.

During interviews with all (100\%) principals, the study established that inadequate ICT facilities in the departments were a major problem since not all members were able to access the ICT facilities. This was making work very hard as each staff was working toward meeting the deadlines. This factor was a hindrance to efficiency of the ICT work performance. The principals further maintained that the inadequacy were due to priority given to ICT by various Board of Management. The principals further noted that in most cases their schools were forced to operate with minimal ICT facilities. Further interviews with all (100\%) secretaries indicated that there were few computers and other ICT equipments in most schools.

Further interviews with the principals indicated that most staff were lacking ICT skills, and were not able to make use of the ICT facilities. The principal added due to lack of skills most staff do prefer to give their secretaries work to do for them and this they maintained was eroding confidentiality of the documents. According to the secretaries majority of staff members were semi skilled in ICT and were still making the secretary work difficult.

Financial difficulty was noted as a major hindrance for the use of ICT in school management. The principals also noted that schools were lacking funds to effectively implement the ICT total usage in the management practices in secondary school. The principal further explained that the free secondary Education funds were meant for specific vote heads and they were not allowed to divert the funds for other usage. The principal also maintained that the cost of ICT equipments were so high that it was not easy to afford purchasing of many ICT facilities.

During interviews with the secretaries, the study established that there was virus infection on the stored data in the ICT facilities. The secretaries also noted that most computers were infected with virus which was destroying the data stored in the computers. The secretaries also noted that most staff was downloading documents that were highly infectious to the stored data. According to the principals, the virus infection was a world phenomenon that require precaution on which computers to be preserved. The principals also maintained that most infected computers were kept and the ones with sensitive data were preserved for only authorized persons.

Due to inadequate skills in ICT, most teachers and other staff were negative attitude on the usage of ICT in management. The principals further noted that the resistance from other staff was due to their fear of monitoring system that would accompany the implementation of ICT in management. According to the secretaries the resistance was a result of laziness among staff that was complaisant with the old system of management. The secretaries also noted that it was not going to be easy for semi illiterate when each worker would be required to use the ICT whenever they had to pre sent their work to the administration. Although ICT had a good storage system, the principals however feared access by authorized persons the confidential data stored on ICT equipments. The principals maintained that storing in the data on ICT was not the best as they could be easily access into by un authorized persons.

\subsection{Strategies of Enhancing ICT in the Delivery of Management Services in Public Secondary Schools.}

The fourth objective was to recommend strategies of enhancing ICT in the delivery of management services in public 
secondary schools. The research question responded to was; what strategies are put in place to enhance ICT use in the delivery of services in public secondary schools in Siaya County

Table 2. Showing strategies of enhancing ICT as reported by principals $(n=43)$, deputy principals $(n=43)$, Heads of Departments $(n=86)$, Secretaries $(n=43)$, Bursars/Clerks $(n=43)$.

\begin{tabular}{lccccc}
\hline \multirow{2}{*}{ Strategies of Enhancing ICT Usage } & $\begin{array}{c}\mathbf{P} \\
\mathbf{f} \%\end{array}$ & $\begin{array}{c}\text { DP } \\
\mathbf{f} \%\end{array}$ & $\begin{array}{c}\text { HOD } \\
\mathbf{f} \%\end{array}$ & $\begin{array}{c}\text { SEC } \\
\mathbf{f} \%\end{array}$ & $\begin{array}{c}\text { BU/CLK } \\
\mathbf{f} \%\end{array}$ \\
\hline Grants from the Government to buy computers & 43100 & 43100 & 86100 & 43100 & 43100 \\
Donation of computers by NGOs and well wishers & 43100 & 43100 & 86100 & 43100 & 43100 \\
Parents' contributions to buy ICT equipments & 43100 & 43100 & 86100 & 43100 & 43100 \\
Prioritize ICT equipments & 4093 & 4093 & 8093 & 4093 & 3888 \\
Organizing ICT workshops /seminars & 3581 & 3377 & 7688 & 3479 & 3377 \\
Educating staff on the importance of ICT use in school administration & 3081 & 2763 & 5766 & 2967 & 3081 \\
\hline
\end{tabular}

KEY: HT= Head Teachers, HoDs =Heads of Departments,

Table 4.10 reveals that there were several strategies that could be used by schools to enhance the use of ICT in the school management system. Among the major steps were, Looking for grants from the government to buy computers, seeking for ICT grants from NGO and using parents contributions for buying computers. Other steps includes; prioritizing ICT equipments in the school board of management, organizing workshops on IT and educating the staff on the importance of ICT on the school administration.

During interview with principals, majority (80\%) principals maintained that they were looking for grants from both the government and donor organizations. This strategy was to help bring more computers to school system. The head teachers also maintained that they were also requesting grants from NGOs to help get new computers. Some (77\%) principals maintained that they were writing proposals through their local politicians to help their schools get grants for purchasing computers or the computers directly from the donors.

During interviews most (97\%) principals maintained that they were trying to connect with various NGOs to donate for them computers. The principals also indicated that they were using politicians and other influential people around their schools to connect them with NGOs so that they could get donations of computers. They were doing this so that their schools could be completely interlinked right from the gate to the principal's office. The principals further explained that using ICT in managing institution was a very good way of monitoring all department while one is inside his/her office.

According to all (100\%) principals their schools were planning to use parents contributions for buying computers and other ICT equipments to enable them be interlinked and managed through ICT. The principals also noted that they were intending to use PTA funds to enable the schools purchase the ICT equipments. According to majority (87\%) principals, they were at higher level of talking with the PTA Executive to approve the use of PTA Funds in purchasing more computers for school management.

During interviews with all (100\%) principals, the study established that the principals were prioritizing ICT equipments in the school board of management. They noted that the board of management was to make their first development agenda for this new financial year. The principals also added that making purchase of ICT equipment a priority was a noble course towards school progress and development. They added that this was the only way of helping them to adequately monitor and control their schools.

Most (85\%) principals noted that they were currently organizing in-house workshops and seminars on the use of ICT in school systems. Such seminars were meant to make the staff understand the usage of ICT as well as to know how to use various equipments in the day to day running of the school affairs. The principals maintained that such workshops were important because most staff members were semi-illiterate when it comes to ICT usage. The principals also indicated that they were aware that some of members their staff had not trained on IT and that warrant the workshops and seminars. Some (66\%) principals maintained that they were currently educating their staff on the importance of ICT on the school administration. This sensitization was necessary because it is a new approach to administration which was surprising many staff.

\section{Summary, Concluson and Recommendations}

\subsection{Summary}

The study established that there were several factors that were limiting the usage of ICT in secondary schools. The study 
indicated that the major factors were; inadequate ICT facilities in the department, few members of staff had skills in the usage ICT equipments, and inadequate finance. Other factors such as virus infection on the stored data, negative attitude of the staff on the usage of ICT in management and fear of access of confidential data stored on ICT equipments. These factors needed to be checked in order for ICT to be properly used in managing schools.

The study also established that there were several strategies that were being used by schools to enhance the use of ICT in the school management system. Among the major steps were, Looking for grants from the government to buy computers, seeking for ICT grants from NGO and using parents contributions for buying computers. Other steps includes; prioritizing ICT equipments in the school board of management, organizing workshops on IT and educating the staff on the importance of ICT on the school administration.

\subsection{Conclusion}

The study established that there were several factors, which were hindering the usage of ICT. Such factors were; inadequate ICT facilities in the department, few members of staff had skills in the usage ICT equipments, inadequate finance, virus infection on the stored data, negative attitude of the staff on the usage of ICT in management and fear of access of confidential data stored on ICT equipments. From the findings, the study concluded that schools should find ways of curbing all these factors to enable proper usage of ICT in school management.

The study established that schools were taking several steps to help in enhancing ICT delivery among such steps were, Looking for grants from the government to buy computers, seeking for ICT grants from NGO and using parents contributions for buying computers. Other steps includes; prioritizing ICT equipments in the school board of management, organizing workshops on IT and educating the staff on the importance of ICT on the school administration. From the above findings, the study concludes that more support should be given to school to enable them achieve their dream of fully implementing the usage of ICT in the management of school activities.

\subsection{Recommendations}

The study also recommends that all factors limiting the usage of ICT should be eliminated through collaboration of all stakeholders such as sponsors, county government, central government, parents and well wishers. The study further recommends training for all stakeholders on the benefits of using ICT in school management.

The study recommends that more strategies should be put in place to enhance the use of ICT in school management. The study further recommends that strategies should be supported by the stakeholders to enable schools achieve their dreams of using ICT in managing their systems

\section{Recommendations for Further Studies}

The following recommendations for further study were made; A study should be conducted to establish the effects of ICT on students finance management in secondary schools.

A study should be conducted on the factors affecting the use of ICT in the management of library resources in secondary schools.

\section{References}

Abid, A. (2004). "Information Literacy for Lifelong Learning" A paper presented at the 70th IFLA General Conference and Council of the World Library and Information in Council, Buenos-Aives-Argentina, UNESCO.

Adamy, P. and Heinecke, W. (2005). The influence of organizational culture on technology Integration in teacher education. Journal of technology and teacher education.

Al- Sharifa, M. (2012). Leadership Practices of Kuwaiti Secondary School Principals for Embedding ICT. Thesis. Gult Comparative Education Society (GCES). Quensland University of Technology.

Amory, A. (1997). Integration of technology into education: theories, technology, examples and recommendations, Contract Report, Open Society Foundation of South Africa, Cape Town.

Boit M.J and Menjo K.D (2012). The Challenges of using Information Communication Technology (ICT) in School Administration in Kenya. Journal of Emerging Trends in Educational Research and Policy Studies (JETERAPS) 3 (1): 55-60: Scholarlink Research Institute Journals, 2012.

Education Blog (2011). Effective Educational Management; Implementation of ICT in Administration of Higher Education Institutions. An October 2011 Publication. 
Borg, R, Gall, M, and Gall, J (2006) Education Research: An Introduction. New York: Longman Publishers.8 th $^{\text {th }}$ dition

Genov, N (1999). Managing Transformations in Eastern Europe. Publication of the Personal and Institutional Strategies for Management of Transformation Risks in Central and Eastern Europe" Project. UNESCO- MOST, Paris. Regional and Global Development Sofia.

Government of Kenya (2005). Kisumu District Strategic Plan 2005-2010. Nairobi: Coordination Agency for Population and Development, Ministry of Planning and National Development.

Government of Kenya (2006). Education Sector Policy Overview Papers: Government Printers, Nairobi.

Government of Kenya, (2005). Siaya District Strategic Plan 2005-2010. Nairobi: National Coordination Agency for Population and Development, Ministry of Planning and National Development.

Government of Kenya, (2002) Siaya District Development Plan. Nairobi, Government Printer.

Gurr, D., (2004). ICT, Leadership in Education and E- Leadership. Discource: Studies in the Cultural Politics of Education. 25 (11) $113-$ 124.

Hawkridge, D. (1993). New Information Technology in Education. Sydney: Groom Helm LTD.

ISRJ (2011). Indian Streams Research Journal; Vol 1, Issue IV; Information and Communication Technology (ICT); Ifotech. Com.

Information Technology Study. Module 2. International Society for Technology in Education

Kashorda , M. Waema, T., Omosa, M. \& Kyalo, V., (2007). E- Readiness Survey of Higher Education in Kenya. Nairobi: Kenya Education Network (KENET).

Kavagi, L. (2001). The Use of Computers in Secondary Schools: A Survey of Schools in Western Province. Unpublished Naster of Philosophy. Thesis. Moi University.

Kekelis, L. S. Ancheta, R.W.Heber, E. and Countryman, J. (2004). Bridging differences: How social relationships and racial diversity matter in a girls' technology program. Unpublished manuscript.

Kenya National Bureau of Statistics, (2009). Economic Survey 2009. Nairobi: The Government Printer.

Kenya School Net, (2003). Preparing a Workforce for the Evolving Information Economy: A Survey on ICT Access and Use in Kenya Secondary Schools, Nairobi: Summit Strategies Limited.

Kiboss, J. K. (2000). Teacher/ pupil perspectives on computer-augmented physics lessons on measurement in Kenyan secondary schools. Journal of Information Technology Education. Vol 9, Issue 2, 2000.

Kinuthia, W. (2009). Educational Development in Kenya and the Role of Information and Communication Technology. International Journal of Education and Development using ICT. (online), 5 (2). Available: http/lijedict.dec. uwi.edu/viewarticle.php?id=740.

Kiptalam G. K \& Rodrigues A.J (2010). Internet Utilization: A Case of Connected Rural and Urban Secondary Schools in Kenya. International Journal of Computing and ICT Research, Vol. 4. No 1, June 2010.

Klawe, M\& Leveson N. (2001). Refreshing the needs. Communications of the ACM.

Kombo, D.K \& Tromp, D.L.A. (2006). Proposal and Thesis Writing: An Introduction. Paulines Publications Africa; Nairobi GPO (Kenya).

Kothari, C. R. (2004). Research Methodology: Methods and Techniques. New Age International (P) Ltd.

Krige K, Okono, P. (2007). Setting up and sustaining e-learning projects. (A paper presented at the $2^{\text {nd }}$ International Conference on ICT for development, education and training at Safari Park Hotel on May $28^{\text {th }}$ to $30^{\text {th }}, 2007$ )

Longe, R. S. and O.G. Agabi (1990). "Status of Management Information System in Higher Education Institute in Nigeria" in African Journal of Educational Management, 4 (1\& 2) PP 104-115.

Makau, B.M \& IDRC, (1990). Computers in Kenya's Secondary Schools: Case study of an innovation in education, Ontario: IDRC.

Mark Gronow, (2007). ICT Leadership in School Education; A Paper presented to the Australian Catholic University Conference. The Sofitel Wentworth, Sydney, Australia.

Ministry of Education Science and Technology (MOEST), (2005): Sessional Paper no.1 of 2005: A Policy Framework for Education, Training and Research, 2005; Nairobi; Government Printer.

Ministry of Education Science and Technology (2008). Final Report on the Kenya Education Management Capacity Assessment (KEMACA), Nairobi, Kenya.

MOEST (2005): Kenya Education Sector Support Programme: 2005-2010. Delivering Quality Equitable Education and Training to All Kenyans; 2005 Draft. Nairobi; Government Printer

MOEST (2005).ICTs in Education Options Paper 2005- Ministry Of Education, Science And Technology. Government of Kenya.

Mohammad, Y., (2006). Factor Influencing the Implementation of ICT in Jigawa States Schools, Nigeria. Unpublished M. Ed. Thesis, University of llorin.

Mugenda, O, and Mugenda O. (2003). Research Method: Quantitative and Qualitative Approaches. Nairobi. Nairobi African Center for Technology (ACTS). P 256.

NEPAD e-Africa Commision (2003). The NEPAD e-Initiative: Ensuring that Young Participate Actively in the Global Information Society and knowledge Economy.http//www.eafricacommission.org

Nthamburi, R. (2011). The role of ICT in curriculum implementation in The PRINCIPAL; Secondary Heads Professional Magazine. Oxford University Press.

Nwagwu, N. A, (1995). The development and Management of Records in the Nigerian Education System in Data Management in Schools and other Issues. Ehiametalor, E.T (ed) Benin-City, Ilupeju Press Limited

Nwosu, A.A, (2003). Integrating ICT into STM Classroom: Status and Implications. Proceeding of the $44^{\text {th }}$ Stan Conference 56 to 60.

Obeng, T. K (2004) "Practical Application of ICT to Enhance University Education in Ghana" in http//www.modernghana.com/ Ghana/tome/New.Achive/feature.asp 
Odera, F. Y. (2002) A study of Computer Integrated Education in Secondary Schools in Nyanza Province, Kenya

Olalere, M. (2005). A middle School Computer Technologies Journal. A service of NC State University, Raleigh NC State University, Raleigh NC. www.ncsu.edu/meridian, Volume 8. Issue 2. Summer 2005

Osodo, J. (1999). Visualization skills incorporation into a Biology undergraduate courses. University of Natal, Durban, South Africa.

Osodo, J. Indoshi F.C, Ongati, O. (2010). Attitudes of students and teachers towards use of computer technology in Geography education. Educ. Res.1(5).

Papert, S. (1992). Mindstorms: Children, Computers and Powerful ideas. New York; Harper, Collins Publishers.

Reffel, P and Whitworth, A. (2002). Information Fluency: Critically Examining IT Education, New Library World, 102 (11-12); 427-435.

Republic of Kenya (2005b) Siaya District Strategic Plan (2005-2010) for implementation of the National Population Policy for Sustainable Development; Ministry of Planning and National Development. Government Printers; Nairobi

Rieber, L. (2005). Multimedia learning in games, simulations, and microworlds. In R. E. Mayer (Ed), The Cambridge Handbook of Multimedia Learning. New York: Cambridge University Press.

Schiller, J. (2002). Surfers or Spectators? Principals and ICT. Principal Matters. March 30-31.

Siaya County (2009). General Information on Kenya: County Fact Sheets; Nairobi; Government Printer.

Slezak James (1984).Odyssey to Excellence: How to Build Effective Schools Through Leadership and Management Skills. Merritt Publishing Company, Millbraae, CA 94030.

Starr, L. (2001). Same time this year. [on-line]. Available at http// www.education-world.com/a tech/tech075.shtml.

Stephenson, J., Ed. (2001). Learner- managed learning- an emerging pedagogy for online learning. Teaching and Learning Online: Pedagogies for New Technologies. London, Kogan Page.

Tanui, E.K (2003). Relative effects of a computer-based instruction in accounting on students' achievement, perception of classroom environment and motivation in secondary schools in Kenya. Doctoral Thesis, Egerton University, Njoro, Kenya.

Tanui,E.K, Kiboss, J.K, Walaba,A.A. \& Nassiuma, D. (2008). Teacher's changing roles in computer assisted roles in Kenyan secondary schools Education Research and Review Vol. 3

Telem, M. (2001). "Computerization of School Administration: Impact on Principals' Role: A Case Study" in Computers in Education, (37) PP 345-365.

Tilya, F. N. (2007). Policy Issues in ICT Education and Training. Available online: tilya@edu.udsm.ac.tz.

Visscher, A. J (1992). Design and evaluation of a Computer- Assisted Management Information System for Secondary Schools (PhD Dissertation). Enschede: University of Twente, Faculty of Educational Science and Technology.

Visscher A. J, and Spuck D. W, (1991). Computer Assisted School Administration and Management: The state of the art in seven nations. Journal of Research on Computing in Education 24 (1) 146-296.

Visscher A, J. Phil, W and Fung, A, (2001).Information Technology in Educational Management: Synthesis of Experience, Research and Future Perspectives on Computer Assisted Computer Information System. Kluwer Academic Publishers, Nertherlands.

Wabuyele, L. (2006). Computer Use in Kenyan Secondary Schools: Implications for Teacher Professional Development. In C. Crawford et al., Proceedings of Society for Information Technology \&Teacher Education International Conference 2006.

Wadi, D; (2004). Jomtiem Declaration article 4: Derived from 'ICT in Education Toolkit, Decision Makers Essentials" Haddad.

World Bank (2007). "Knowledge and Skills for the Information Age: The First Meeting of the Mediterranean Development Forum," in Mediterranean Development Forum.

Yusuf, M. O (2005). "Information and Communication Technology" Analyzing the Nigerian National Policy for Information Technology in International Educational Journal (3)PP 316-321. 